\title{
A SYSTEMATIC LITERATURE REVIEW ON THE TITANIUM METAL PRODUCT VALUE CHAIN
}

\author{
R.N. Roux ${ }^{1,2 *}$, E. van der Lingen ${ }^{1}$ \& A.P. Botha ${ }^{1}$
}

\section{ARTICLE INFO}

Article details

Presented at the $30^{\text {th }}$ annual conference of the Southern African Institute for Industrial Engineering (SAIIE), held from 30 September - 2 October 2019 in Port Elizabeth, South Africa

Available online $\quad 15$ Nov 2019

Contact details

Corresponding author nicky.roux7@gmail.com

Author affiliations

1 Department of Engineering and

Technology Management,

Graduate School of Technology and Innovation Management, University of Pretoria, South Africa

2 Light Metals, Materials Science \& Manufacturing, Council for Scientific and Industrial Research (CSIR), Pretoria, South Africa

DOI

http://dx.doi.org/10.7166/30-3-2233
ABSTRACT

This article presents a systematic literature review (SLR) on the titanium metal product value chain. Globally this value chain is fragmented, meaning that successive production stages rarely occur within the same country, and information published on the value chain is limited. The aim of this review was to collect the literature to create and elaborate on the titanium metal product value chain. The SLR followed a combined building block searching strategy and a criterion analysis to obtain relevant literature on production stages in the value chain. The value chain was based on the three main sections that comprise the titanium metal industry: the raw material, the processes and technologies, and the market. From the main sections, eight production stages were identified and discussed. Arising from the literature review, these stages will be applied as a baseline to understand the requirements for improving the underdeveloped titanium industry in South Africa.

\section{OPSOMMING}

Die artikel is 'n sistematiese literatuur studie (SLS) oor die titaan metaal produk waardeketting. Op 'n globale vlak is die titaan waardeketting baie gefragmenteer. Dit beteken dat opeenvolgende produksiefases selde in dieselfde land plaasvind, met die gevolg dat min navorsing op die totale waarde ketting gepubliseer word. Die doel van die SLS was om literatuur te versamel wat kan bydrae tot die identifisering en uitbreiding van die titaan metaal produk waardeketting. Die toegepaste proses vir die SLS was 'n kombinasie van 'n bou-blok soek-strategie gevolg deur 'n kriteria analise. Drie hoof seksies in die titaan industrie is identifiseer: die rou materiaal, prosesse en tegnologieë, en die mark. Die hoof seksies is toe verder opgedeel in agt geïdentifiseerde produksie fases en elke fase is apart bespreek. Die agt geïdentifiseerde fases se relevansie tot die Suid-Afrikaanse titaan industrie sal toegespits word om die toepaslikheid in 'n plaaslike industrie te bestudeer.

\section{INTRODUCTION AND BACKGROUND}

Titanium metal is popularly referred to as 'the wonder metal'. It exhibits numerous unique properties that make it ideal for selected applications within niche high-value industries. Although it is an abundant element in nature, pure titanium metal is rare. Titanium is mined as an enriched ore that undergoes several production stages to produce a finished titanium product. All of these stages can be covered in three main sections: the raw material, the processes and technologies, and the market [1].

The three sections can be sub-divided into eight production stages. Each stage is dependent on its specific precursor and, in turn, is needed to produce the product for the next stage. This outlines the titanium metal product value chain, as displayed in Figure 1. The dotted lines indicate alternative routes that can be followed to reach the final stages, which are milled products and powder products. 


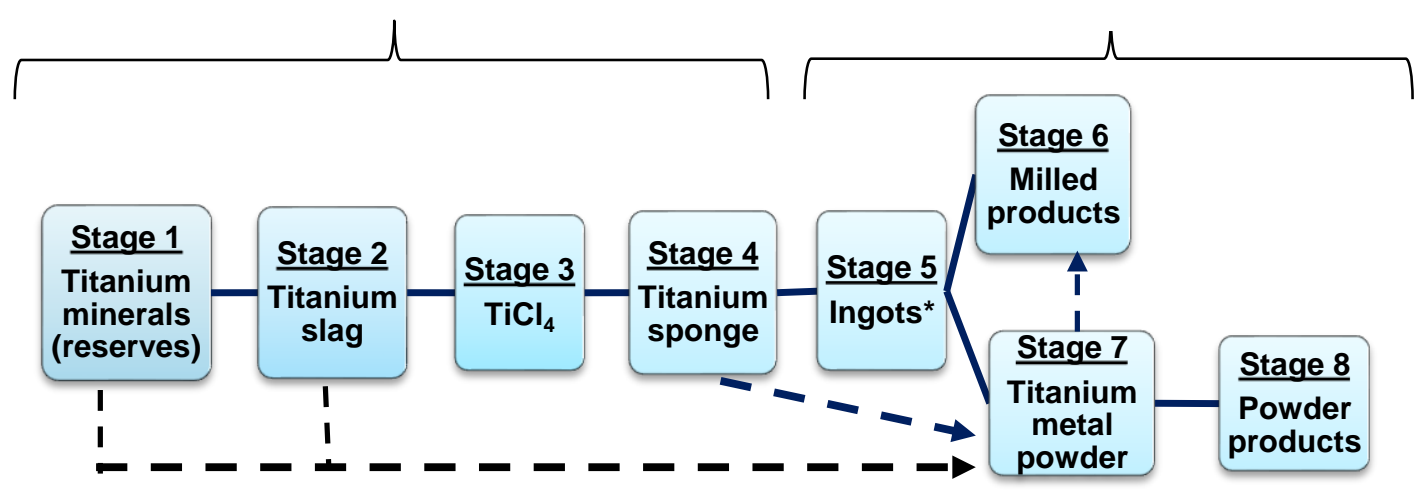

Figure 1: The titanium metal product value chain

The titanium product value chain is fragmented $[2,3]$. This means that most of the production stages shown in Figure 1 do not occur within the same country [4].

In the late 1990s, the South African government identified the titanium metal and titanium oxide industries as one of the promising industries that should be re-evaluated and developed locally $[5,6]$. South Africa has the world's fourth-largest titanium mineral reserves, and was the largest producer of mined titanium in 2017 [7]. Based on these statistics, one would assume that the country has a thriving titanium industry; but the technological gap for further processing (post-mining) for highvalue downstream applications is large. South Africa does not have an existing titanium product value chain, but is involved only in selected stages of the upstream and downstream processes.

The aim of this study is systematically to review the available literature on the titanium metal product value chain on a global and local scale. The information gathered will contribute to the establishment of the South African titanium industry by highlighting which stages of the product value chain need to be developed.

\section{REVIEW METHOD}

A systematic literature review (SLR) can be defined as a systematic, explicit, comprehensive, and repeatable method to evaluate the available literature $[8,9]$. It strives to identify, to evaluate critically, and to integrate the literature available on a specific research topic $[10,11]$. The research topic for the SLR presented in this paper is the different stages of the titanium metal product value chain.

In order to comply with the criteria of an SLR, a step-by-step approach needs to be established for the collection of the relevant literature. Creswell [12] provided a list of five stages for a literature review:

1. The identification of key terms (keywords or key-phrases).

2. Conducting a topic-based search in relevant databases.

3. Critically evaluating the collected literature and selecting the relevant documents.

4. Organising the literature in a systematic order.

5. Writing the literature review, consisting of a summary of the information.

\subsection{Identification of keywords}

Based on the titanium product value chain (see Figure 1), keywords were selected to enable a comprehensive search for each stage of the value chain. It was decided to refer to these words as key-phrases, as some phrases are composed of two or more words. A distinction was made between primary key-phrases and secondary key-phrases. The phrases were selected based on the product(s) produced during each stage of the value chain. Related words or synonyms of the phrases were also included in the search. As this study is on the titanium metal product value chain, it was decided to include the phrase 'value chain' as a secondary key-phrase. The results for the search of the phrase 'value chain' search will be discussed separately. 


\section{Primary key-phrase}

1. Titanium AND titanium metal

\section{Secondary key-phrases:}

1. Titanium reserves

2. Titanium slag

3. Titanium tetrachloride

4. Titanium sponge

5. Ingots

6. Metal powder

7. Wrought or milled product

8. Powder products / near net shape

\subsubsection{Relevant databases}

Based on a search comparison conducted in both the Scopus and the EBSCOhost databases, the Scopus database was selected. This selection was made based on the larger quantity of hits obtained using the same primary and secondary search phrases. The Scopus database also includes several relevant databases, such as ScienceDirect, Taylor and Francis, and the Wiley Online Library. Scopus is one of the most extensive databases, and so is immensely popular in the social science and engineering disciplines [13]. It is the largest abstract and citation database of peer-reviewed literature, and covers science, technology, medicine, social sciences, and the arts and humanities [14]. Scopus also allows a graphical analysis of the search results.

\subsubsection{Study selection}

For the database search, only peer-reviewed articles and reviews were considered. In order to obtain the most relevant literature on the selected topic, it was decided to apply two search strategies: the building block searching strategy and a criterion analysis [11,13]. The principle behind the building block searching strategy is to start with a single or primary concept search (keyword or keyphrase) that will produce a large number of hits [15]. After completing the single concept search, the search should be combined with Boolean operators (secondary key-phrases) that will reduce the number of hits and act as a secondary search [15]. A criterion analysis works on the basis of eliminating literature that does not meet a set of pre-determined criteria [13].

For this SLR, the first step was the application of the building block searching strategy. With this strategy, the primary key-phrase, identified in Section 2.1, was searched and the hits noted. The primary key-phrase - 'titanium and titanium metal' - was included in every search. Next, the primary key-phrase, together with the secondary key-phrases, was searched using a string created by applying Boolean logic, such as AND, OR, and NOT. This is where synonyms and related phrases were added to obtain optimal search results. Table 1 displays the secondary key-phrases and the search input for each secondary phrase.

Table 1: Secondary key-phrases used in the building block searching strategy

\begin{tabular}{|c|c|}
\hline Secondary key-phrase & Search input \\
\hline Titanium reserves & ('reserves' OR ‘ilmenite deposit*' OR 'rutile deposit*') \\
\hline $\begin{array}{l}\text { Titanium slag / upgraded } \\
\text { ilmenite /rutile ore }\end{array}$ & $\begin{array}{c}\text { ('titanium slag' OR 'upgraded ilmenite' OR 'rutile ore') w/5 ('production' } \\
\text { OR 'synthesis') }\end{array}$ \\
\hline $\mathrm{TiCl}_{4} /$ Titanium tetrachloride & (' $\mathrm{TiCl}_{4}$ ' OR 'titanium tetrachloride') w/5 ('production’ OR 'synthesis') \\
\hline Titanium sponge & ('titanium sponge') w/5 ('production’ OR ‘synthesis') \\
\hline Ingots / blooms / billets / slabs & $\begin{array}{c}\text { ('ingot”’ OR ‘bloom*' OR 'billet*' OR 'slab*’) w/5 ('production’ OR } \\
\text { 'synthesis') }\end{array}$ \\
\hline $\begin{array}{l}\text { Milled products / wrought } \\
\text { products }\end{array}$ & $\begin{array}{l}\text { ('milled product*' OR 'wrought product*' OR 'wrought mill product*' OR } \\
\text { 'forging product*') OR ('cast"' w/5 'product') }\end{array}$ \\
\hline Metal powder & ('titanium powder”') w/5 ('production' OR ‘synthesis') \\
\hline $\begin{array}{l}\text { Powder products / near net } \\
\text { shape }\end{array}$ & $\begin{array}{l}\text { ('powder* product”' OR 'near net shape') w/5 ('production’ OR } \\
\text { 'synthesis') }\end{array}$ \\
\hline
\end{tabular}

An asterisk (*) can substitute for the absence of one or more characters, and is useful when including plurals W/5 is a proximity operator that finds words that are far apart - in this case, up to five words apart. 
The second step of this SLR was to eliminate all the literature that did not meet the inclusion criteria. These criteria were established to narrow the field down to a manageable number of articles, but also to ensure that each key-phrase was represented at least once. The first criterion (A) was applied to keep the literature recent by only including literature published during the last 20 years. The second criterion (B) was to exclude documents that mention $\mathrm{TiO}_{2}$ (titanium pigment). Titanium pigment forms a large part of the overall titanium industry, but as the process differs greatly from titanium metal production, it was decided to exclude pigment from the search. The third criterion $(C)$ excluded articles published on keywords that fall outside of the scope of titanium metal. The fourth and last criterion (D) was applied to limit the results only to documents containing the key phrase in the title. A summary of the criteria is displayed in Table 2.

Table 2: Criteria for methodological screening (adapted from Khumalo and Van der Lingen, 2017)

\begin{tabular}{|c|l|}
\hline Symbol & \multicolumn{1}{c|}{ Definition of criteria } \\
\hline A & A timeframe of the last 20 years applied (1999-2019) \\
\hline B & Documents containing titanium pigment in the title excluded $\left(\mathrm{TiO}_{2}\right)$ \\
\hline C & $\begin{array}{l}\text { Exclude documents that refer to } \mathrm{TiCl}_{4} \text {, used as a coagulant in water, by excluding the following } \\
\text { words or phrases: coagulation, coagulant, floc, polytitanium, polymerization, unclassified drug, } \\
\text { titanium nitride }\end{array}$ \\
\hline $\mathrm{D}$ & Only include documents that contain the primary key-phrase in the title \\
\hline
\end{tabular}

\section{RESULTS FROM CONDUCTING A TOPIC-BASED SEARCH}

As the main theme of the SLR is the titanium metal product value chain, the key-phrases formed the basis of all the searches performed. To ensure that all the hits obtained from the search were peerreviewed articles and peer-reviewed reviews, this filter was applied to the Scopus database before any search was conducted. Any results discussed from this point on were subject to this filter.

After limiting the hits to peer-reviewed articles and peer-reviewed reviews, the two proposed search strategies were applied to the Scopus database. The number of hits from the building block search strategy and from the criterion analysis are displayed in Table 3.

Table 3: Article hits in the Scopus database from applying the two search strategies

\begin{tabular}{|c|c|c|c|c|}
\hline \multirow{2}{*}{\multicolumn{2}{|c|}{ Search strategy }} & \multicolumn{2}{|c|}{ Key-phrases } & \multirow{2}{*}{ Search output (number of hits) } \\
\hline & & Primary & Secondary & \\
\hline \multirow{2}{*}{\multicolumn{2}{|c|}{ Building block searching strategy }} & $x$ & & 311162 \\
\hline & & $\mathrm{x}$ & $x$ & 802 \\
\hline \multirow{4}{*}{ Criterion analysis } & A & $\mathrm{x}$ & $\mathrm{X}$ & 504 \\
\hline & B & $x$ & $\mathrm{X}$ & 486 \\
\hline & $\mathrm{C}$ & $\mathrm{x}$ & $x$ & 445 \\
\hline & $\mathrm{D}$ & $\mathrm{X}$ & $\mathrm{X}$ & 144 \\
\hline
\end{tabular}

Following the design, the first criterion (A) reduced the field to articles published within the last 20 years. Second, with criterion $\mathrm{B}$, any article mentioning $\mathrm{TiO}_{2}$ in the heading was removed from the selection. Criterion C eliminated articles that did not fall within the field of study, and last, criterion D only included articles that contained the key-phrase, 'titanium' or 'titanium metal', in their title.

To ensure that all the identified value chain stages were covered in the results, a separate search that included the secondary key-phrase(s) was conducted. The literature collected from each separate search was used in the literature review section. Table 4 indicates the hits obtained for each stage of the titanium metal product value chain. 
Table 4: Indication of the quantity of articles that contained each of the secondary keyphrases

\begin{tabular}{|c|c|c|}
\hline Secondary key-phrases & Key-phrase and Boolean operator used in search & $\begin{array}{l}\text { Hits in the } \\
\text { Scopus } \\
\text { database }\end{array}$ \\
\hline Titanium reserves & ('reserves' OR 'ilmenite deposit"' OR 'rutile deposit") & 22 \\
\hline $\begin{array}{l}\text { Titanium slag / upgraded } \\
\text { ilmenite /rutile ore }\end{array}$ & $\begin{array}{c}\text { ('titanium slag' OR ‘upgraded ilmenite' OR ‘rutile ore') w/5 } \\
\text { ('production' OR ‘synthesis') }\end{array}$ & 11 \\
\hline $\begin{array}{l}\mathrm{TiCl}_{4} / \mathrm{Titanium} \\
\text { tetrachloride }\end{array}$ & $\begin{array}{c}\text { ('TiCl4’ OR ‘titanium tetrachloride') w/5 ('production’ OR } \\
\text { 'synthesis') }\end{array}$ & 14 \\
\hline Titanium sponge & ('titanium sponge') w/5 ('production’ OR ‘synthesis') & 17 \\
\hline $\begin{array}{l}\text { Ingots / blooms / billets } \\
\text { / slabs }\end{array}$ & $\begin{array}{c}\text { ('ingot"' OR ‘bloom*' OR 'billet"' OR 'slab*') w/5 ('production' } \\
\text { OR 'synthesis') }\end{array}$ & 15 \\
\hline $\begin{array}{l}\text { Milled products / } \\
\text { wrought products }\end{array}$ & $\begin{array}{l}\text { ('milled product*' OR 'wrought product"' OR 'wrought mill } \\
\text { product"' OR 'forging product*') OR ('cast*' w/5 'product") }\end{array}$ & 23 \\
\hline Metal powder & ('titanium powder*') w/5 ('production’ OR ‘synthesis') & 29 \\
\hline $\begin{array}{l}\text { Powder products / near } \\
\text { net shape }\end{array}$ & $\begin{array}{c}\text { ('powder* product"' OR ‘near net shape') w/5 (production OR } \\
\text { synthesis) }\end{array}$ & 28 \\
\hline \multicolumn{2}{|r|}{ Total: } & 159 \\
\hline
\end{tabular}

The total number of articles represented in Table 4 is 159 . This number is higher than the 144 articles obtained from the search criteria. The reason for this is that some articles are represented in more than one stage of the value chain, and so were counted twice in Table 4 . The stages most represented from the literature search, in descending order, were metal powder (synthesis), powder products, milled products, and titanium reserves. Stages with the fewest hits, in ascending order, were titanium slag, titanium tetrachloride, ingots/blooms/billets/slabs, and titanium sponge.

The phrase 'value chain' was included in the search, as the aim of this research was to establish the titanium metal product value chain. Only two hits containing this phrase were obtained. This is a clear indication that the titanium value chain, or the titanium metal value chain, is not discussed frequently in the literature. This discovery therefore acts as a motivation for this study to understand the gaps in the titanium metal value chain in a South African context.

\section{CRITICALLY EVALUATING AND ANALYSING THE RELEVANT DOCUMENTS}

The Scopus database provides an online function to analyse the search results. This analysis yielded insight into the results by providing a visual analysis. Seven categories were expanded on: year of publication, article source, article author(s), affiliation, country/territory of publishing, document type, and the disciplines. A total of 144 articles were submitted for analysis. It was decided to conduct a search analysis on these 144 articles, as statistics on the lower hit counts for each individual stage would not be as accurate.

\subsection{Year of publication}

Articles displayed in the search results represent selected literature published during the last 20 years. Figure 2 displays the number of peer-reviewed articles published during this period. From the figure, an increasing publication trend can be observed. Two years in particular presented more publications than the rest. These were 2005 and 2017.

In 2017 a total of 18 selected articles were published; in 200511 articles were published. The main topics for these two years are displayed in Figure 3. 


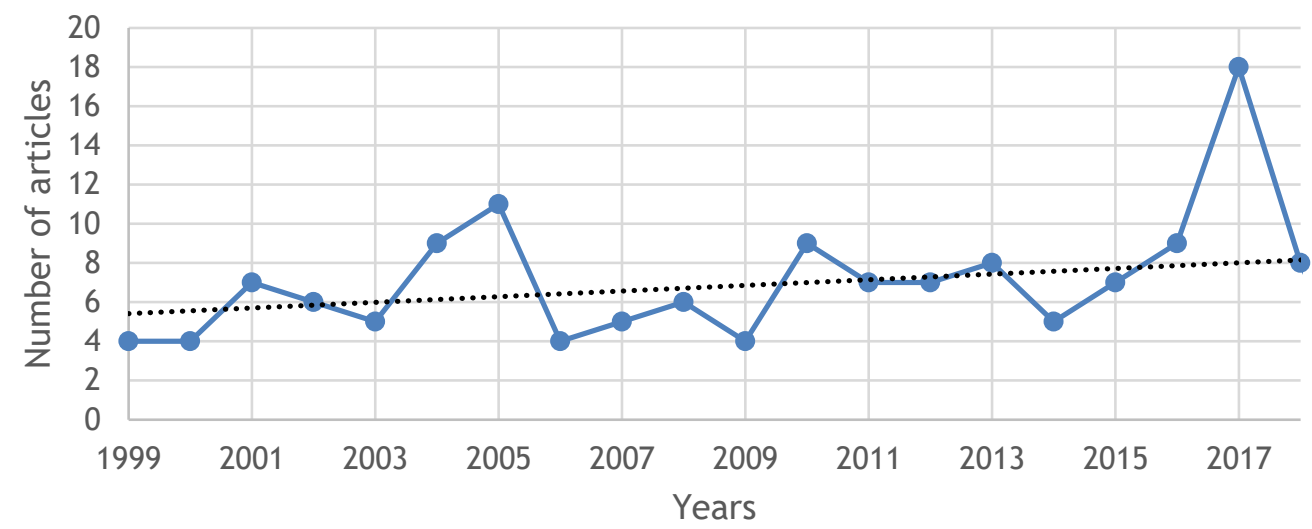

Figure 2: Articles published per year

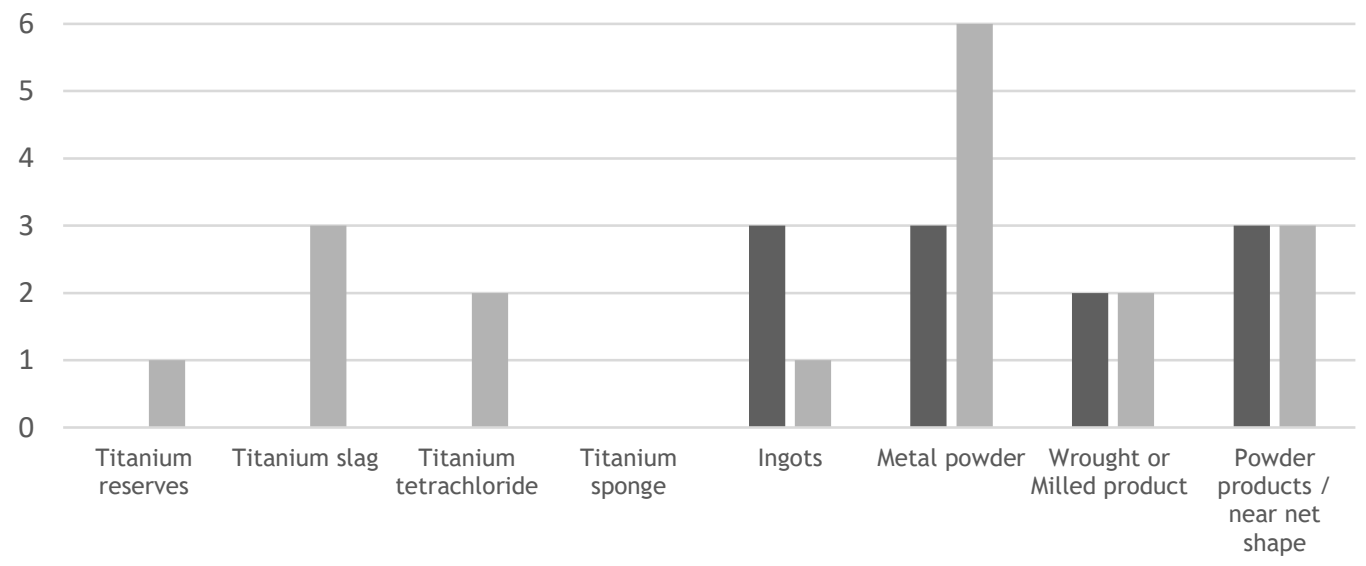

Figure 3: The main topics of articles published in 2005 and 2017

From Figure 3 it can be observed that much more research was conducted on the downstream processing of titanium during both years. This confirms that upstream processes are more established and that research is focusing on the downstream processing of titanium metal. One-third of the articles published in 2017 discussed the production of titanium metal powder (stage 7 on the value chain).

\subsection{Article sources, countries of publication, and affiliations}

The sources with the most publications were the Journal of Metallurgy, Material Science and Engineering, and Metallurgical and Materials Transactions (B Process Metallurgy and Materials Processing Science), each with four publications. The next seven journals all published three articles each. The affiliation with the most articles associated with it was the National Academy of Sciences in Ukraine, with five publications. Countries that dominated the publications were China with 36 and the United States with 24 . More information on the publishing countries and affiliations can be found in Table 1. 
Table 5: Top publishing countries and affiliations from SLR search results

\begin{tabular}{|l|l|}
\hline \multicolumn{1}{|c|}{ Countries } & \multicolumn{1}{c|}{ Affiliations } \\
\hline China (36) & National Academy of Sciences in Ukraine (5) \\
United States (24) & Ministry of Education, China (4) \\
Japan (12) & Tohoku University (4) \\
India (8) & University of Science and Technology, Beijing (4) \\
& University of Idaho (4) \\
& Ufa State Aviation Technical University (3) \\
& Indian Institute of Technology, Bombay(3) \\
& Institute for Materials Research, Tohoku University (3) \\
& Chinese Academy of Sciences (3) \\
& Russian Academy of Sciences (3) \\
& Boeing Corporation (3) \\
& Yunnan Minzu University (3) \\
\hline
\end{tabular}

It is important to note that the top five countries are also well-known for their involvement in the various stages in the titanium metal industry; however, this falls outside of the scope of this study. Another important observation is that most of the affiliations are universities or tertiary institutions, except for Boeing Corporation. Boeing is one of the leading companies in the aerospace field, and it is interesting to note that this company is also invested in titanium research. Aerospace is one of the leading industries for the consumption of titanium metal.

South Africa produced three articles: two were on the chemical properties of finely-milled titanium alloy powders $[16,17]$, and one was on the beneficiation of ilmenite to form a high-purity titanium slag [18].

\subsection{Authors}

The leading authors identified by the SLR are Froes, Chen, Peng, Ramakrishnan, and Valiew. The author with the most publications was Froes, with five articles. Chen, Peng, Ramakrishnan, and Valiew each published three articles. Articles published by these authors formed a key part of the literature review discussed later in this study.

\subsection{Type of document and disciplines}

One of the filters applied to the search was to display results contained in articles and review articles only. Articles made up 94 per cent of the results (136 documents) and reviews a mere six per cent of the results (eight documents).

Titanium and its applications cover diverse disciplines. A total of 15 different disciplines were identified from the search results. This can be expected from the results, as titanium metal is used in a broad spectrum of applications. The proportions of the disciplines are displayed in Figure 4.

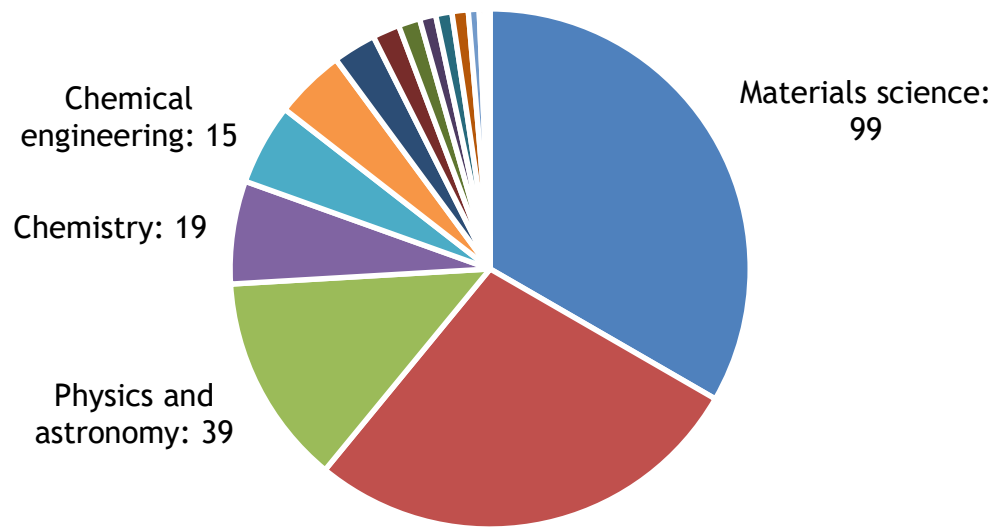

Engineering: 82

Figure 4: Disciplines contained in search results (see online for colour version) 
Other disciplines not labelled in Figure 4, in decreasing order, are the earth and planetary sciences; environmental science; energy; biochemistry, genetics and molecular biology; computer science; mathematics; medicine; business, management and accounting; pharmacology, toxicology and pharmaceutics; and the social sciences.

\section{ORGANISING THE LITERATURE IN SYSTEMATIC ORDER}

In order to arrange the literature in a systematic order, it was decided to address the articles based on each stage of the value chain. All of the articles were imported into Mendeley (a referencing software). A manual screening was then conducted per stage, and articles with irrelevant topics were removed. The bulk of the removed articles contained information that was considered too technical for this study. The refined article count was 140 . The article counts, and the articles arranged per topic, can be seen in Table 6 .

Table 6: Articles relevant to each of the eight stages of the titanium metal product value chain

\begin{tabular}{|c|c|c|c|}
\hline Stage in value chain & $\begin{array}{c}\text { Initial article } \\
\text { count }\end{array}$ & $\begin{array}{c}\text { Refined article } \\
\text { count }\end{array}$ & $\begin{array}{c}\text { Articles selected for literature } \\
\text { review }\end{array}$ \\
\hline Titanium reserves & 22 & 11 & {$[19,20,29,21-28]$.} \\
\hline Titanium slag & 11 & 11 & {$[18,30,39,31-38]$.} \\
\hline Titanium tetrachloride & 14 & 9 & {$[40-48]$.} \\
\hline Titanium sponge & 17 & 17 & {$[40,44,56-62,45,49-55]$.} \\
\hline Ingots & 15 & 14 & {$[62,63,72-75,64-71]$} \\
\hline Wrought or milled products & 23 & 21 & {$[16,17,84-93,76,94,77-83]$} \\
\hline Metal powder & 29 & 29 & {$[42,95,104-110,96-103]$} \\
\hline $\begin{array}{c}\text { Powder products / near net } \\
\text { shape }\end{array}$ & 28 & 28 & $117]$ \\
\hline Totals & 159 & 140 & \\
\hline
\end{tabular}

Stage 1 , titanium reserves, obtained the most irrelevant hits (articles). The main reason for this is that the results for stage 1 mainly discussed the chemical compositions of specific titanium reserves and not the preferred quantity of reserves worldwide. Half of the articles from this stage were not included for the theoretical background section of this SLR.

\section{THEORETICAL BACKGROUND}

The SLR search methodology was designed to collect literature on the eight identified stages of the titanium metal product value chain. Each stage is represented by a production stage needed for the subsequent stage (see Figure 1).

Section 5 organised the collected articles into the eight identified stages. Some articles contained information relevant to more than one stage. A brief literature review now follows on each of the stages, as well as a short description on the quality of the literature obtained through the search.

\subsection{Titanium reserves (Stage 1)}

Titanium deposits occur in three industrial groups: coastal-marine and alluvial (stream) placer deposits; primary ore deposits; and the weathering crust of carbonatite complexes [29]. Most of the titanium reserves are confined to primary ore deposits, but placer deposits, also referred to as 'heavy mineral concentrates', are more economically feasible to mine [25,29]. The two most important titanium minerals are ilmenite $\left(\mathrm{FeTiO}_{3}\right)$ and rutile $\left(\mathrm{TiO}_{2}\right)$, of which ilmenite is the most common [25]. Bykhovskii and Tigunov [29] indicate that the major regions for titanium mining are Australia, Africa (including South Africa), India, China, Kazakhstan, Russia, Ukraine, Canada, and Chile.

The literature on reserves collected in this SLR can be divided into three main groups. Five of the articles discussed the beneficiation potential of specific reserves; four articles discussed the characterisation of the different deposits, and how they differ from one another; and two articles were country-specific - Russia and Finland respectively - and discussed those countries' reserves.

A disadvantage identified from the collected literature was the absence of quantified titanium reserves by country. It should be noted that titanium reserves are reported on a yearly basis by 
consultancy firms, and that these reserve reports are not peer reviewed articles. The latest global reserves were thus not obtained from the literature.

\subsection{Titanium slag (Stage 2)}

The iron (among other contaminants) confined in ilmenite's crystal lattice is seen as a contaminant that should be removed through beneficiation [34]. The product that is formed though beneficiation (smelting) is titanium-rich slag $\left(80-90 \% \mathrm{TiO}_{2}\right)$, and further purification produces a product called synthetic rutile $\left(92-95 \% \mathrm{TiO}_{2}\right)[33,34,37,38]$. The required purity of the beneficiated product is dependent on the titanium product specification [38]. Samal [37] stated that titanium dioxide (rutile) is mainly used in the paint (titanium pigment), paper, plastic, and fertiliser industries, and ilmenite is mainly used as an intermediate feedstock for the production of titanium metals [37].

All of the articles obtained from Stage 2 of the literature search discuss the production of upgraded titanium slag or synthetic rutile. The main processes discussed were smelting processes, the reduction of ilmenite to convert ferric iron to ferrous iron, the reduction of iron in ilmenite to the metallic form followed by corrosion with ammonium chloride and oxygen, the Murso process, and the Enhanced Roasting and Magnetic Separation (ERMS) process [34].

\subsection{Titanium tetrachloride $-\mathrm{TiCl}_{4}$ (Stage 3)}

$\mathrm{TiCl}_{4}$ is the most common precursor of titanium sponge and titanium metal powder [44]. $\mathrm{TiCl}_{4}$ is produced from rutile and upgraded titanium slag, mainly through the chloride process [44] (also referred to as the 'fluidised bed chlorination process'), which is the main process used for sponge and titanium metal production [35]. It is important to note that crude $\mathrm{TiCl}_{4}$ still contains impurities, and that this liquid needs to undergo purification before titanium metal or titanium sponge can be produced. These impurities are removed by physical means (different boiling points) or by chemical means (reagents such as hydrogen sulphide and organic matter) [44].

The articles obtained from the $\mathrm{TiCl}_{4}$ search cover a wide range of results. Some of the results discuss the use of $\mathrm{TiCl}_{4}$ for the production of either titanium sponge or titanium metal powder. One of the articles elaborated on a novel method that produces titanium in its liquid state using a pilot high temperature electrowinning cell [41]. Environmental concerns about working with chlorine were also highlighted in a qualitative risk assessment that discussed the release of $\mathrm{TiCl}_{4}$ during the production of titanium sponge [45].

\subsection{Titanium sponge (Stage 4)}

The Kroll process is the main process used for the production of titanium sponge $[40,57]$. This process is semi-batch, in which purified $\mathrm{TiCl}_{4}$ is continuously fed into a reactor containing a molten magnesium solution. The magnesium solution acts as a reductant, and the result is the production of titanium sponge in a reactor [40,57]. The salt that forms from this reaction $\left(\mathrm{MgCl}_{2}\right)$ is tapped out of the reactor as it forms [57]. Economically and chemically, the Kroll process is not ideal, and several research initiatives have attempted to improve on this process [57]. Alternative processes have attempted to replace the Kroll process, but none have succeeded on an industrial scale. One example is the Hunter process, which uses sodium instead of magnesium; but the last commercial plant was closed in 1993 [52,57,62].

Titanium sponge-related articles that the SLR identified elaborated on improvements to the Kroll process. These included additional laboratory scale tests, the development of arc-sprayed coatings for the high temperature reactors, and the improvement on sponge quality by chloride removal using vacuum distillation $[40,49,60]$. The articles also elaborated on waste neutralisation and processing [55] and the impact that sponge production has on the environment [52]. To emphasise the safety issues related to the production of titanium sponge (such as working with chlorine and working at high temperatures), two risk assessments were included in the search results - one on the Kroll plant's operation and one on $\mathrm{TiCl}_{4}$ waste generation [45,59].

\subsection{Ingots (Stage 5)}

Titanium sponge is still a crude form of titanium metal, and it has to undergo heat treatment processes to become a usable form of titanium or titanium alloy [74]. Titanium has a strong affinity for oxygen and nitrogen; therefore titanium sponge cannot be melted in conventional refractories [62]. The result is that titanium sponge needs to be melted in a water-cooled copper crucible that is either in a vacuum or in an inert atmosphere [62]. Processes to melt titanium are electron-beam remelting (EBR), vacuum arc melting and remelting (VAR), plasma arc remelting (PAR), and electro- 
slag remelting (ESR) $[62,65]$. Heat treatment allows for the production of homogeneous electrodes that can then be processed into ingots, blooms, billets, or slabs of titanium and titanium alloys [65]. To illustrate the processes involved in the production of ingots, the process flow of a VAR furnace is shown in Figure 5.

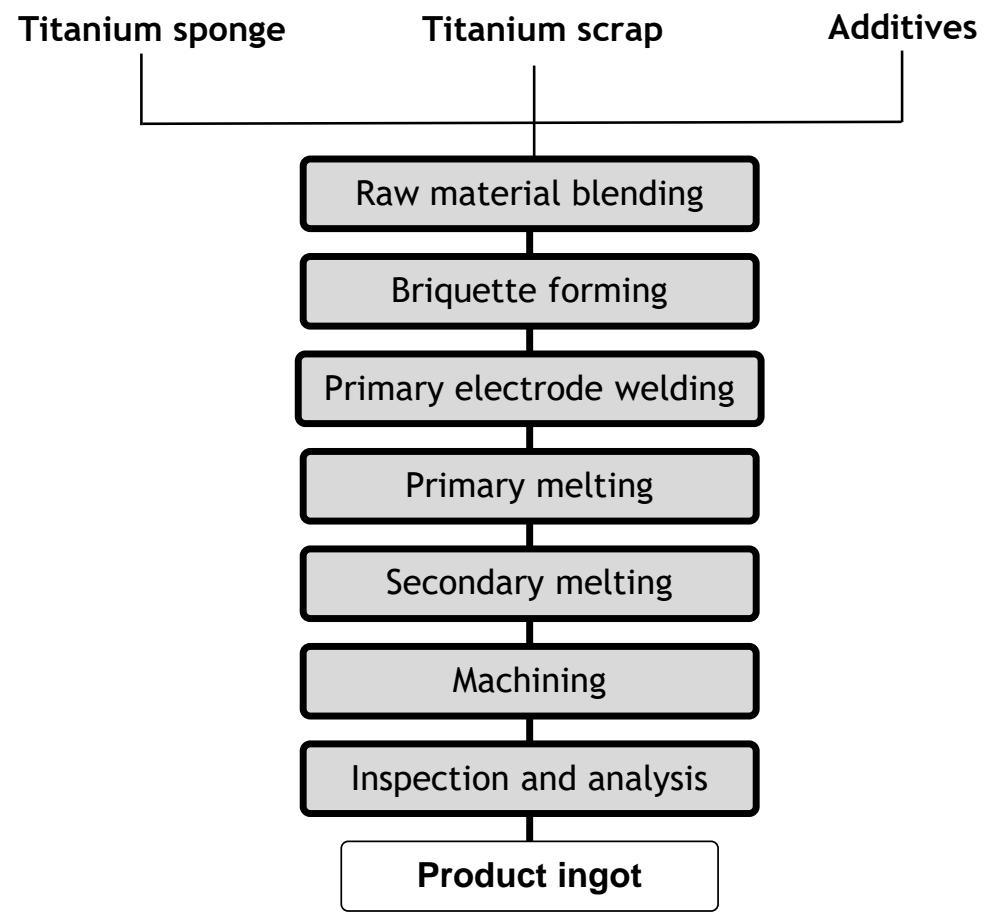

Figure 5: Processing steps to produce an ingot through VAR (adapted from [62])

One of the major drawbacks of the use of titanium metal is the high cost of titanium semi-finished products [74]. This cost is exaggerated by each processing step, and is a reflection of the complexity of the production process [74]. Titanium also has a low metal utilisation factor (also referred to as 'the buy-to-fly ratio'), meaning that large amounts of scrap are generated compared with the product produced. These drawbacks are forcing the industry to develop and implement promising new manufacturing technologies [74].

The titanium market is becoming competitive, with new technologies forcing non-competitive producers out of business [62]. From the literature obtained from the SLR, this is clearly visible in the advances being applied in several heat treatment techniques. Paton, Trigub and Zhuk [65] discussed the benefits of electron beam remelting above those of vacuum-arc melting. Some of these benefits were the elimination of the electrode production phase, the ability to produce ingots that are round or rectangular, the production of structurally and chemically homogeneous ingots from one re-melt, and an increase in available metal yield [65]. Dobatkin and Anoshkin [64] discussed the elemental segregation that occurs during VAR, and the benefits and shortcomings of this segregation. Some of the literature provided more detailed chemical information on microstructure evolution during the ingot formation process and the oxygen content of the product ingot [69].

\subsection{Wrought or milled products (ingot metallurgy) (Stage 6)}

The conventional titanium metal product value chain (metal from Kroll sponge) is seen as the mainstream titanium production stream [136]. For this conventional value chain, the finished milled or wrought product is the end of the chain, and the product is ready for the market. Dutta and Froes [93] discussed the cost of these final products, mentioning that the downstream production of the final products (such as casting, forging, and rolling) contributes most to the high titanium product cost (Figure 6) [93]. This high cost is related to the machining of the ingots, blooms, billets, and slabs, which creates a high buy-to-fly ratio [93]. 


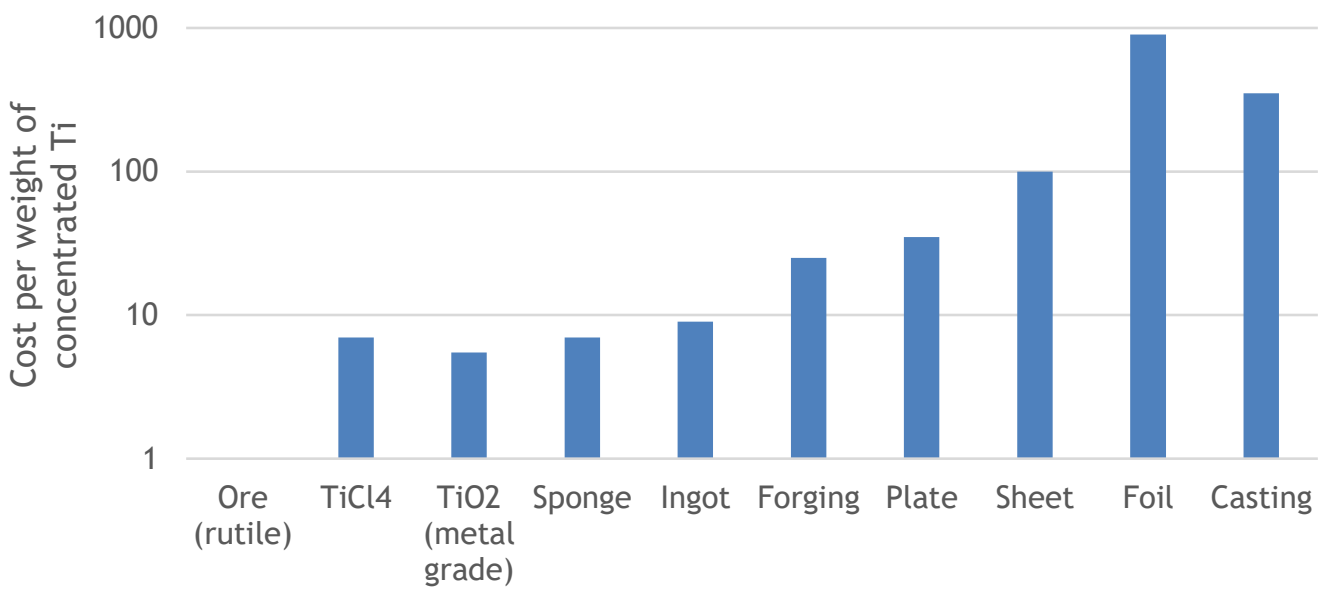

Figure 6: Cost of titanium at various stages of component fabrication ([93])

Articles obtained from the SLR search discussed finished products that are produced as wrought and milled products, as well as the latest developments to improve the processes. One of the processes that was discussed is the continuous casting process. The continuous casting of billets has proved to be more economical and ecologically efficient than casting in molds [88]. To improve this method further, Kuberskii, Essel'bakh and Novokhatskii [88] investigated the effect that different concentrations of titanium have on the mechanical properties of the continuously casted billets. Articles containing more detailed chemical research were also included in the search results; some discussed the effects that heat treatment has on the microstructure and mechanical properties of both wrought and cast (milled) products $[79,137]$. This is especially important for products that need to meet the demand for aircraft structure parts [137].

The articles obtained from the literature search discussed several markets that use milled and wrought products. These include the chemical field, where pipes are used in heat exchangers [83]; the biomedical field, where titanium alloys are used for dental implants [85]; the aerospace industry, where titanium alloys are the material used to produce propellant tanks (welding of domes and rings) [91]; and the military field (casting components for light-weight weapons) [129]. Titanium milled and wrought products are also used for recreational purposes, such as golf club heads, bicycles, motorcycle parts, and automotive turbocharger wheels [81,92].

A limitation observed from the literature search on milled and wrought products is that no mention was made of the market size of wrought and milled products in the titanium industry. The articles obtained from the SLR did not quantify the impact for the different industries, as each article was limited to discussing only one such industry or product.

\subsection{Metal powder (Stage 7)}

Modern metallurgy is increasingly developing powder metallurgy (PM) [130] - the application of metallurgical processes that use metal powders to produce metal products [136]. The main reason for the growth in PM is the potential to apply cost reduction methods through the production of near net shape products for structures with complex geometries $[130,136]$.

Several techniques have been developed to produce titanium metal powder. These can be divided into two mainstream processes: powder from sponge [138] and powder from direct electrochemical reduction [134]. Powders produced from titanium sponge dominate the powder supplies [126]. These powders mainly undergo the hydride-dehydride $(\mathrm{HDH})$ process, or a variety of centrifugal atomisation techniques [136]. Powders produced by the HDH process are relatively coarse and have an angular morphology. Powders from the atomisation techniques are mostly spherical with a high purity $[130,136]$. Spherical powders are generally expensive to produce [130].

Several countries are devoted to developing a method to produce titanium powder from direct electrochemical reduction [104]. The literature obtained from this SLR discussed the following processes: 
- The Fray-Farting-Chen (FFC) process (now 'Metalysis') in the United Kingdom. This process employs the direct electrochemical reduction of rutile minerals to obtain a high purity titanium within molten calcium chloride [52,134].

- The preform reduction process in Japan. This process is based on the calciothermic reduction of preform containing $\mathrm{TiO}_{2}[134,139]$. The Ono-Suzuki process is a variation of this process.

- The Australian TiRO process. This is a continuous process for the direct production of commercially pure (CP) Ti powder. The process is composed of two steps. In step one, $\mathrm{TiCl}_{4}$ and magnesium powder react in a fluidised bed to form small titanium metal particles. In the second step, these particles (dispersed between spheroidal $\mathrm{MgCl}$ particles) are vacuum-distilled to remove the $\mathrm{MgCl}$ particles. In the last step, the titanium particles combine to form a sintered shell-like structure. The titanium is then ground to produce titanium powder [104].

- The Armstrong process in the USA. This process entails the direct reduction of $\mathrm{TiCl}_{4}$ with liquid sodium [100].

- The combustion synthesis (CS) powder production technique in South Korea. This process involves the direct reduction of $\mathrm{TiO}_{2}$ to Ti during combustion [99]. After combustion the powder is spheredised to prepare the powder for further processing [99].

- The CSIR process (South Africa). This process involves direct electro-chemical reduction of $\mathrm{TiCl}_{4}$ in a molten salt [104].

The literature obtained for the powder production stage of the titanium metal product value chain mainly focused on the different techniques used to produce titanium powder. In addition to the powder production techniques, the literature obtained from the SLR also discussed the processing steps of the powder. The conventional processing of titanium powder includes press-and-sintering and additive manufacturing [136], but the literature also refers to the production of products normally associated with titanium sponge. This was evident in an article published by Gogaev et al. [110] on the production of titanium powder sheets.

\subsection{Powder products / near net shape (Stage 8)}

In an effort to reduce the cost of titanium products, two research routes have been established. Powder metallurgy (PM) plays an important part in both routes. The first is the development of novel methods to extract titanium metal (discussed in section 6.7), and the second is the development of creative fabrication technologies for titanium products [119].

The main fabrication routes established for PM titanium component production include metal injection moulding (MIM), cold isostatic pressing (CIP), hot isostatic pressing (HIP), near net shape HIP (NNS-HIP), and various free-form fabrication (or rapid manufacturing) routes such as 3D printing [126]. It is, however, important to note that powders produced from different methods have different shapes, sizes, and purities, and will therefore be processed differently, each for a specific end use [130].

Products produced from titanium powder (including titanium alloys) are increasingly being preferred above milled or wrought products. The reasons for this include the lower buy-to-fly ratio, the ability to produce complex shapes (such as inner cavities and shapes), the potential to reduce residual stresses (which are normally established during production), and the ability to work in a vacuum chamber, thereby lowering contamination of the metal with oxygen $[115,118]$.

The literature obtained from the SLR discussed the use of titanium and titanium alloy products for several markets. The main industries discussed were aerospace, biomedical, and automobile. The use of titanium powder in these industries can mainly be attributed to the metal's strength-toweight-ratio, its resistance to corrosion, and its low density [115].

The aerospace industry is one of the major consumers of titanium metal [140]. This industry dominates titanium consumption; more specifically, wrought titanium products dominate titanium consumption [121]. Powder products for the aerospace industry are forced to compete with the wrought products, and the sensitivity of powder to oxygen is one of the main challenges [121]. Examples of powder products used in the aerospace industry include jet-engine parts (in gas turbines) and fasteners $[4,126]$.

For the biomedical industry, titanium and its alloy foams have been identified as a lightweight, biocompatible, and porous material that is suitable to improve fixation and enhance bone in-growth [118]. The metal has been used successfully as a material for artificial hip joints and dentistry 
implants [115,118]. Tuncer, Arslan, Maire and Salvo [118] indicated that powder metallurgy is the preferred process in the biomedical industry, as it provides a high degree of freedom and allows for the production of a wide range of structures.

In contrast to the porous products required by the biomedical industry, the automobile industry wants a fully dense material (such as for gearshift knobs) $[4,117,132]$. The quality of the product can be improved by using a specific powder (such as gas-atomised pre-alloyed powders to avoid swelling), combined with the most suitable process (such as HIP to densify the material) to obtain the required metal properties [132].

Other components produced from titanium metal powder include toy components, surgical tools, rifle and firearm components, watch cases, watch bands, watch clasps, eyeglasses components and frames, cell phone hinges and knuckles, heat valves, golf clubs, implant devices, cosmetic cases, and decorative hardware for luggage and purses [4].

The literature collected from the SLR search mainly discussed the operation and improvement of the MIM technique for powder products $[4,116,117,124]$. A large overlap in the articles published on powder production (stage 7 ) and powder products (stage 8 ) was also observed; these articles were discussed under powder production.

\section{DISCUSSION OF FINDINGS AND RESULTS}

The literature obtained from the SLR has sufficient information on each stage of the value chain. Information from the articles, collected on the different stages of the titanium product value chain, can be split to represent the upstream and downstream sections of the value chain.

The upstream processes are represented by stages 1 to 4 , and mainly discuss the raw and impure forms of titanium. Titanium is an abundant element, and the most economical deposits to mine are placer deposits where the heavy minerals have accumulated (stage 1). The purest natural form of titanium is the rutile mineral $\left(\mathrm{TiO}_{2}\right)$, but the ilmenite $\left(\mathrm{FeTiO}_{3}\right)$ mineral is more abundant. The beneficiation processes for the two minerals differ slightly, and after beneficiation an upgraded slag or synthetic rutile (stage 2 ) is used to produce $\mathrm{TiCl}_{4}$ (stage 3 ). $\mathrm{TiCl}_{4}$ is seen as the pre-cursor of titanium metal, as most downstream processes are dependent on this intermediate product. $\mathrm{TiCl}_{4}$ can either be thermos-chemically processed to form titanium sponge (mostly through the Kroll process) (stage 4), or it can undergo a direct electrochemical reduction to produce titanium metal powder (stage 7). Titanium sponge needs further processing to produce a usable form of titanium metal. This is achieved by several phases of heat treatment to produce ingots, blooms, and billets of slabs (stage 5).

The downstream section of the value chain is represented by processes and products of titanium metal and metal alloys. There are two main pathways for the downstream section. In the first pathway, the ingots (stage 5) are machined and fabricated into milled or wrought products (stage 6). In the second pathway, titanium metal powder (stage 7) is consolidated into a powder product (stage 8).

From the upstream section (stages 1 to 4), the collected literature theme was based on established technologies with minor adaptations for small improvements. The main theme observed from the articles collected in the downstream section (stages 5 to 8 ) was to reduce the cost of titanium in order to make the metal more accessible to the standard consumer, thus growing the market.

Although the literature did not directly address the fragmented nature of the industry, it could be seen that each article only represented detailed information on one or two consecutive stages of the value chain. South Africa featured in four stages of the value chain. First, it was mentioned that the country has abundant titanium reserves (stage 1) [29]. Second, Nell [18] discussed the production of titanium slag from ilmenite (stage 2). The third mention of South Africa was for research to produce titanium powder (stage 7) [104], and last was the research done on titanium powders for further processing (stage 8) $[16,17]$. 
The South African titanium metal value chain is underdeveloped. In order for the country to improve its titanium metal industry, it would need to invest time and money in building a commercially viable segment of the titanium metal product value chain. The South African government is committed to growing the current value chain, as shown by ongoing research into the missing stages of the value chain. One such example is the drive to develop a technology to produce titanium metal powder. This SLR forms part of a bigger study that will revisit this approach. Based on the literature obtained in the SLR, it is recommended that a vision should be defined for the products and markets on which the country should focus, and the processing gaps that need to be filled to achieve the vision should be identified. Such a vision should guide a titanium roadmap in the context of the fragmented value chain.

The fragmented nature of the global titanium metal product value chain contributes to the limited amount of information available on the value chain. It is therefore recommended that the accuracy of the value chain used in this SLR should be reviewed and tested. It is also recommended that a study be conducted to evaluate the extent of the global titanium metal value chain's fragmentation.

\section{REFERENCES}

[1] Du Preez, W., Damm, O. \& Jordaan, J.. 2013. Titanium milled products: Roadmap for SA. Pretoria South Africa.

[2] Cardarelli, F. 2013. Materials handbook, $3^{\text {rd }}$ ed. Canada: Springer.

[3] ILUKA. 2015. Mineral sands industry information. [Published by ILUKA Resources Limited, Available from: http://www.iluka.com/docs/default-source/mineral-sands-briefing-papers/150525- --ilu-briefing-paper-marketingevolution-(final).pdf?sfursn=2]

[4] German, R.M. 2010. Status of metal powder injection molding of titanium. Int. J. Powder Metall., 46(5), 11-17.

[5] Van Tonder, W. 2010. South African titanium: Techno-economic evaluation of alternatives to the Kroll process. [Publication details needed - Published by the University of Stellenbosch. South Afroca.

[6] Van Vuuren, D. S. 2009. Keynote address: Titanium - an opportunity and challenge for The 7th International Heavy Minerals Conference 'What next'. Published by: The Southern African Institute of Mining and Metallurgy) pp 1-8

[7] USGS. 2018. Mineral commodity summaries. Available from: https://pubs.er.usgs.gov/publication/70194932

[8] Fink, A. 2014. Conducting research literature reviews: From the internet to paper, $4^{\text {th }}$ ed. Thousand Oaks, California: SAGE. Available from: https://univofpretoria.on.worldcat.org/oclc/829744169

[9] Okoli, C. 2017. A guide to conducting a standalone systematic literature review. Commun. Assoc. Inf. Syst., 37(1/43), pp 879-910.

[10] Siddaway, A. 2104. What is a systematic literature review and how do I do one? Available from: https: / pdfs.semanticscholar.org/2214/2c9cb17b4baab118767e497c93806d741461.pdf

[11] Even-Zahav, E., \& Kelly, C. 2016. Systematic review of the literature on 'informal economy' and 'food security'. Published by the Institute for Povery, Land and Agratoam Stidoes, Univerisy of the Western Cape.

[12] Creswell, J. W. 2012. Education Research: Planning conducting and evaluating quantitative and qualitative research ed P A Smith. Fourth Edition. Published by: Boston: Pearson.

[13] Khumalo, M. and Van der Lingen, E. 2017. The Open Business Model in a Dynamic Business Environment: a Literature Review South African J. Ind. Eng. 28 pp147-60.

[14] CSIR Information Services. 2018. CSIR Electronic Resources A-Z. Available from: http: / /csiris.csir.co.za/finding-information/electronic-resources-a-z/

[15] Miner. 2008. Building Block Search Strategy Elem. Available from: http://miner94.blogspot.com/2008/07/building-block-search-strategy.html

[16] Maweja, K., Phasha, M. J. and Yamabe-Mitarai, Y. 2012. Alloying and microstructural changes in platinum-titanium milled and annealed powders J. Alloys Compd. 523 pp167-75

[17] Maweja, K. Cornish, L. A. and Can, N. 2011. Transformation and alloying mechanisms in substoichiometric titanium carbonitrides - Tungsten high energy ball milled powders Int. J. Refract. Met. Hard Mater. 29 pp 312-9.

[18] Nell, J. 2000 An overview of the phase-chemistry involved in the production of high-titanium slag from ilmenite feedstock J. South African Inst. Min. Metall. 100 pp 35-44

[19] Miao, L. C. and Lin, F. 2014. A novel technology for recovering Iron, titanium and vanadium from a low grade titanic magnetite ores Int. J. Earth Sci. Eng. 7 pp 67-70

[20] Xu, C., Zhang, Y., Liu, T. and Huang, J. 2017. Characterization and pre-concentration of low-grade vanadium-titanium magnetite ore Minerals 7. Published by MDPI AF. Available from https: / / www.scopus.com/inward/record.uri?eid=2-s2.0-

$.85027323503 \& d o i=10.3390 \% 2 F m i n 7080137 \&$ partner $I D=40 \& m d 5=42$ fac3972a $447723 \mathrm{a} 04 \mathrm{~d} 26 \mathrm{cbfe} 5 \mathrm{ffc} 03$. 
[21] Ni, P., Zhu, X., Wang, R., Shen, K., Zhang, Z., Qiu, J, and Huang, J. 2008. Constraining ultrahigh-pressure (UHP) metamorphism and titanium ore formation from an infrared microthermometric study of fluid inclusions in rutile from Donghai UHP eclogites, eastern China Bull. Geol. Soc. Am. 120 1296-304

[22] Yang, F. X, Li. W. M., Chen, D., Qiao, J. L., Liang, L. J., He, Y. Z., Li, W. H. and Jiaia, H. 2010. Discussion on the deposit features and genetic characteristics of vanadium-titanium magnetite ore in Xiaohongshan, Western Inner Mongolia Northwest. Geol. 43 pp 66-74

[23] Liu, Y., Ding, H. and Xie, D. 2014 Titanium resource and the environmental effects of sponge titanium production in China Earth Sci. Front. 21 pp 281-93

[24] Lyutoev, V. P., Makeev, A. B. and Lysyuk, A. Y. 2017. Exploring a possibility to determine titanium magnetite ores mineral composition by spectroscopy data. Published by "Ore and Metals" Publishing house. Obogashchenie Rud. pp 28-36

[25] Sarapää, O., Kärkkäinen, N., Ahtola, T. and Al-Ani, T. 2015. High-tech metal potential in Finland with emphasis on rare earth elements (REE), titanium and lithium Cent. Eur. Geol. 58 pp 291-305

[26] Zanaveskin, K. L., Maslennikov, A. N., Makhin, M. N. and Zanaveskin, L. N. 2016. Influence of granulometric composition on leucoxene concentrate processing with titanium tetrachloride obtaining (Yaregskoe Deposit) Tsvetnye Met. pp 79-85

[27] Andrews, W. J., Moreno, C. J. G. and Nairn, R. W. 2013. Potential recovery of aluminum, titanium, lead, and zinc from tailings in the abandoned Picher mining district of Oklahoma Miner. Econ. $26 \mathrm{pp}$ 61-9

[28] Liu, C.R., Wang S.J., Feng J.M., Li, X. Y., Fu, S. H., Ouyang, Z. Y. and Zheng, Y. C. 2007. The geochemistry evidence for selecting the suitable raw material in China to simulate the low titanium lunar soil from luna-sea basalt Kuangwu Yanshi 27 pp 28-33

[29] Bykhovskii, L. Z. and Tigunov, L. P. 2011. Titanium raw materials of Russia Russ. J. Gen. Chem. 81 pp 1328-1344

[30] Zhang, Y., Fang Z. Z., Xia, Y., Huang, Z., Lefler, H., Zhang, T., Sun, P., Free, M. L. and Guo, J. 2016. A novel chemical pathway for energy efficient production of Ti metal from upgraded titanium slag Chem. Eng. J. 286 pp 517-27

[31] Wangs, S., Guo, Y. F., Jiang, T., Chen, F., Zheng, F. Q., Tang, M. J., Yang, L. Z. and Qiu, G. Z. 2018. Appropriate titanium slag composition during smelting of vanadium titanomagnetite metallized pellets Trans. Nonferrous Met. Soc. China (English Ed. 28 2528-37

[32] Fan, H., Chen, D., Liu, T., Duan, H., Huang, Y., Long, M. and He, W. 2018 .Crystallization behaviors of anosovite and silicate crystals in high $\mathrm{CaO}$ and $\mathrm{MgO}$ titanium slag Metals (Basel). Available from: https: / / www.scopus.com/inward/record.uri?eid=2-s2.085054665763\&doi=10.3390\%2Fmet8100754\&partnerID=40\&md5=22c78e7b317417510a805b94dda9bf90

[33] Chen, G., Chen, J. and Peng, J. 2015. Effects of mechanical activation on structural and microwave absorbing characteristics of high titanium slag Powder Technol. 286 pp 218-22

[34] Mehdilo, A. and Irannajad, M. 2012. Iron removing from titanium slag for synthetic rutile production Physicochem. Probl. Miner. Process. 48 pp 425-39

[35] Fan, H., Duan, H., Tan, K., Li, Y., Chen, D., Long, M. and Liu, T. 2017. Production of Synthetic Rutile from Molten Titanium Slag with the Addition of B2O3 JOM 69 pp 1914-9

[36] Li, Y., Chen, G., Peng, J., Srinivasakannan, C. and Ruan, R. 2017. Study of the oxygen reduction of low valent titanium in high titanium slag by microwave rapid heating Powder Technol. 315 pp 318-21

[37] Samal, S. 2016 Synthesis and Characterization of Titanium Slag from Ilmenite by Thermal Plasma Processing JOM 68 pp 2349-58

[38] Dang, J., Fatollahi-Fard, F., Pistorius, P. C. and Chou, K.-C. 2018 Synthesis of Titanium Oxycarbide from Titanium Slag by Methane-Containing Gas Metall. Mater. Trans. B Process Metall. Mater. Process. Sci. 49 pp 123-31

[39] Zheng, X., Cheng, G., Chen, J., Peng, J., Srinivasakannan, C. and Ruan, R. 2018 Preparation of synthetic rutile from high titanium slag using microwave heating Phase Transitions 91 308-15

[40] Lee J C, Sohn H S and Jung J Y 2012 Effect of TiCl 4 feeding rate on the formation of titanium sponge in the kroll process J. Korean Inst. Met. Mater. 50 pp 745-51

[41] Ginatta, M. V. 2004. Extractive Metallurgy of Primary Titanium Light Met. Age 62 48-51

[42] Moxson, V. 2000 Powder developments reduce the cost and boost the market for titanium parts Mater. Technol. 15 pp 187-91

[43] Xu, C., Yuan, Z. and Wang, X. 2006. Preparation of TiCl4 with the titanium slag containing magnesia and calcia in a combined fluidized bed Chinese J. Chem. Eng. 14 pp 281-8

[44] Wang, X., Zhang, L., Shang, G., Zhang, G., Yuan, J. and Gong, S. 2009. Processing copper-vanadium precipitate formed from crude $\mathrm{TiCl} 4$ in titania and titanium sponge production Hydrometallurgy 99 pp 259 62

[45] Roy, P. K., Bhatt, A. and Rajagopal, C. 2003 Quantitative risk assessment for accidental release of titanium tetrachloride in a titanium sponge production plant J. Hazard. Mater. 102 pp 167-86

[46] Merrill, C. C. and Couch, D. E. 2017 Separation Of Columbium, Tantalum, Titanium, And Zirconium From Titanium Chlorination Residues. U S Bur Mines, Rep Invest RI. Available from: Separation Of Columbium, Tantalum, Titanium, And Zirconium From Titanium Chlorination Residues

[47] Zhang, Y., Wang, W., Guo, G. and Liu, L. 2000 Synthesis of titanosilicalite using titanium tetrachloride as titanium source Chinese J. Catal. 21 pp 197-8

[48] Sana, S. 2002. Titanium tetrachloride (TiCl4) Synlett 364-5. Available from: https: / / www.scopus.com/inward/record.uri?eid=2-s2.00036167271\&partnerID=40\&md5=5612be027907993bbcc67f1dbbda8ddf 
[49] Zhang, Z. L., Gong, X. and Zhang, N. N. 2015. Arc-sprayed Coatings for High Temperature Reactors in Titanium Sponge Process High Temp. Mater. Process. 34 pp 311-6

[50] Xu, G. and Wang, G. 2009 Development of titanium and its industry Xiyou Jinshu / Chinese J. Rare Met. 33 pp 903-12

[51] Osypenko, 0. 2015 Development of technology of obtaining raw materials for titanium alloys made of offgrade titanium sponge EasternEuropean J. Enterp. Technol. 4 pp 28-32

[52] Gao, F., Nie, Z., Yang, D., Sun, B., Liu, Y., Gong, X. and Wang, Z. 2018. Environmental impacts analysis of titanium sponge production using Kroll process in China J. Clean. Prod. 174 pp 771-9

[53] Nagesh, R. V. S., Ramachandran, C. S. and Subramanyam, R. B. 2008. Methods of titanium sponge production Trans. Indian Inst. Met. 61 pp 341-8

[54] Ratnikov, V. I., Prokudina, V. K., Belikova, A. F. and Sachkova, N. V. 2010. Obtaining of titanium powder from titanium sponge by self-propagating high-temperature synthesis hydration and dehydration Russ. J. Non-Ferrous Met. 51 pp 352-8

[55] Kudryavskii, Y. P. 2004 Physicochemical principles and technology of processing and neutralization of titanium production wastes Russ. J. Appl. Chem. 77 pp 701-7

[56] Feng, Z., Yixiang, C. and Miaolin, H. 2005. Powder metallurgy technological testing of substandard titanium sponge of China. Published by: Guangzhou Research Institute of Nonferrous Metals, Guangzhou 510651, China. Xiyou Jinshu Cailiao Yu Gongcheng/Rare Met. Mater. Eng. 343

[57] Fuwa, A. and Takaya, S. 2005. Producing titanium by reducing $\mathrm{TiCl2}-\mathrm{MgCl} 2$ mixed salt with magnesium in the molten state JOM 57 pp 56-60

[58] Zhadkevich, M. L., Shapovalov, V. A., Konstantinov, V. S., Stepanenko, V. V., Torkhov, G. F., Burnashev, V. R., Rejda, N. V. and Kolesnichenko, V. I. 2005. Production of consumable electrodes by titanium sponge compaction under current Probl. Spetsial'noj Electrometallugii pp 58-61

[59] Roy, P. K., Bhatt, A. and Rajagopal, C. 2004. Quantitative risk assessment in titanium sponge plant Def. Sci. J. 54 pp 549-62

[60] Liang, L., Dachun, L., Heli, W., Kaihua, L., Juhai, D. and Wenlon, G. J. 2018 Removal of chloride impurities from titanium sponge by vacuum distillation Vacuum 152 pp 166-72

[61] Guo, F., Yang, H. B., Xie, F., Tan, H. and He, J. L. 2009. Study on the gas chromatographic analysis of the purity of silicon tetrachloride recovered from the titanium sponge production Yejin Fenxi/Metallurgical Anal. 29 pp 51-5

[62] Kosemura. S., Fukasawa, E., Ampo, S., Shiraki, T. and Sannohe, T. 2002. Technology trend of titanium sponge and ingot production Nippon Steel Tech. Rep. 31-5. Available from: https: / / www.scopus.com/inward/record.uri?eid=2-s2.00036252969\&partnerID=40\&md5=c82162ba73f16ee4256bb0b6d0f18776

[63] Lei, J. and Xue, Z. 2016. Cause analysis for large titanium inclusion in wire rod cord steel Jiangsu Daxue Xuebao (Ziran Kexue Ban)/Journal Jiangsu Univ. (Natural Sci. Ed. 37 pp 670-4)

[64] Dobatkin, V. I. and Anoshkin, N. F. 1999. Comparison of macrosegregation in titanium and aluminium alloy ingots Mater. Sci. Eng. A 263 pp 224-9

[65] Paton, B. E., Trigub, N. P. and Zhuk, G. V. 2008. Crystallization of titanium ingots in the course of electron-beam melting Mater. Sci. 44 pp 328-35

[66] Minay, E. J., Rawlings, R. D. and McShane, H. B. 2004. Hot extrusion reaction synthesis of nickel, titanium and iron aluminides J. Mater. Process. Technol. 153-154 pp 630-6

[67] Jablokov, V. R., Murray, N. G. D., Rack, H. J. and Freese, H. L. 2005. Influence of oxygen content on the mechanical properties of titanium-35Niobium-7Zirconium-5Tantalum beta titanium alloy J. ASTM Int. 2 pp 445-56

[68] Borisovskaya, E. M., Nazarenko, V. A., Podrezov, Y. N., Koryak, O. S., Evich, Y. I. and Gorban,' V. F. 2008. Mechanical properties of powder titanium at different production stages. I. Densification curves for titanium powder billets Powder Metall. Met. Ceram. 47 pp 406-13

[69] Dyakonov, G. S., Mironov, S., Semenova, I. P., Valiev, R. Z. and Semiatin, S. L. 2017. Microstructure evolution and strengthening mechanisms in commercial-purity titanium subjected to equal-channel angular pressing Mater. Sci. Eng. A 701 pp 289-301

[70] Li, M. L., Wang, H., Yang, Z. G., Feng, X. X., Chen, J. W., Jia, Y. H. and Wang, H. Z. 2011. Original position statistic distribution analysis of carbon, silicon, manganese, phosphorus, sulfur, niobium, titanium, vanadium in the cross section of different middle and low alloy steel continuous casting slabs Yejin Fenxi/Metallurgical Anal. 31 pp 1-8

[71] Ryabtsev, A. D. and Troyanskij, A. A. 2001. Production of ingots of titanium, chromium and alloys on their base in chamber electroslag furnaces using "active" metal-containing fluxes Probl. Spetsial'noj Electrometallugii pp 6-10. Available from: https://www.scopus.com/inward/record.uri?eid=2-s2.0$0035778337 \&$ partnerID=40\&md5=6381731cb6538e15f39190b5c116f630.

[72] Vakhrusheva, V. S., Buryak, T. N., Ladokhin, S. V. and Levitski, N. I. 2001. Use of a cast billets of new type in the production of titanium tubes Metall. i Gornorudn. Promyshlennost pp 60-3

[73] Zhuk, G. V., Kalinyuk, A. N. and Trigub, N. P. 2004. Production of titanium ingots-slabs using method of EBCHM Probl. Spetsial'noj Electrometallugii 20. Available from: https: / / www. scopus.com/inward/record.uri?eid=2-s2.08644258364\&partnerID=40\&md5=d34421f09640d453d5d46bc5b0fa34e1

[74] Kochetkov, A. S., Nochovnaya, N. A. and Bokov, K. A. 2016. Technology for Making Sparingly Alloyed Titanium Foundry Alloy VT40L Metallurgist 59 pp 964-7 
[75] Liu, Q. L., Jiang, Y. H. and Li, X. M. 2018. The effect of bulk nucleation parameters on the formation of macroscopic grain of the large-scale titanium slab ingot during EBCHM Mater. Sci. Technol. (United Kingdom) 34 pp 1649-56

[76] Cotton, J. D., Clark, L. P. and Phelps, H. R. 2002. Titanium alloys on the F-22 fighter airframe Adv. Mater. Process. $160 \mathrm{pp} 25-8$

[77] Groneck, D. and Harmon, D. 2003. Design development of unitized titanium structure J. Eng. Gas Turbines Power 125 pp 252-6

[78] Froes, F. H., Senkov, O. N. and Qazi, J. I. 2004. Hydrogen as a temporary alloying element in titanium alloys: Thermohydrogen processing Int. Mater. Rev. 49 pp. 227-45

[79] Stauffer, A. C., Czyryca, E. J. and Koss, D. A. 2005. The influence of processing on the microstructure and properties of the titanium alloy Ti-5111. Materials Forum Volume 29

[80] Boyer, R. R. and Briggs, R. D. 2005. Titanium cost reduction strategies for boeing aircraft. Materials Forum. Volume 29

[81] Demukai, N. and Tsushima, K. I. 2005. Development of a new type titanium casting technology: LEVICAST process J. Adv. Mater. 37 12-6

[82] Bera, S. and Manna, I. 2006. Hexagonal close packed to face centered cubic polymorphic transformation in nanocrystalline titanium-zirconium system by mechanical alloying J. Alloys Compd. 417 104-8

[83] MacKenzie, P. M., Walker, C. A. and McKelvie, J. 2007. A method for evaluating the mechanical performance of thin-walled titanium tubes Thin-Walled Struct. 45 pp 400-6

[84] Kolachev, B. A. and Egorova, Y. B. 2008. Mechanohydrogen treatment of titanium alloys with rough turning Met. Sci. Heat Treat. 50 pp 265-8

[85] Tsutsumi, H., Niinomi, M., Akahori, T., Nakai, M., Takeuchi, T. and Katsura, S. 2010. Quality improvement of a B-type titanium alloy cast for biomedical applications by using a calcia mold Mater. Trans. 60 pp 170-6

[86] Do-Nascimento-Rosa, S., Diniz, A. E., Andrade, C. L. F. and Guesser, W. L. 2010. Analysis of tool wear, surface roughness and cutting power in the turning process of compact graphite irons with different titanium content J. Brazilian Soc. Mech. Sci. Eng. 32 pp 234-40

[87] Rabiezadeh. A., Hadian, A. M. and Ataie, A. 2012. Preparation of alumina/titanium diboride nanocomposite powder by milling assisted sol-gel method Int. J. Refract. Met. Hard Mater. 31 pp 121-4

[88] Kuberskii, S. V., Essel'bakh, V. S. and Novokhatskii, A. M. 2012. Continuous casting of billets made of a chromium-nickel titanium-containing corrosion-resistant steel Russ. Metall. 2012 pp 509-13

[89] Xu, Q., Gabbitas, B., Matthews, S. and Zhang, D. 2013. The development of porous titanium products using slip casting. J. Mater. Process. Technol. 213 pp 1440-6

[90] Edwards, P. and Ramulu, M. 2015. Fatigue performance of Friction Stir Welded titanium structural joints Int. J. Fatigue 70 pp 171-7

[91] Gupta, R. K., Kumar, V. A. and Chhangani, S. 2016. Study on Variants of Solution Treatment and Aging Cycle of Titanium Alloy Ti6Al4V J. Mater. Eng. Perform. 25 pp 1492-501

[92] Park, J. B., Lee, J. I. and Ryu, J. H. 2017. Microstructure of titanium aluminide prepared by centrifugal investment casting for automotive turbocharger J. Ceram. Process. Res. 18 pp 399-403

[93] Dutta, B. and Froes, F. H. 2017. The Additive manufacturing (AM) of titanium alloys vol 72 (Elsevier Ltd).

[94] Liang, X., Xu, Z., Zhao, K., Nie, M., Rao, J. and Wang, D. 2017. Interfacial Reaction of Zirconium Sand Mold with Titanium Alloy Castings Based on SLS Method Tezhong Zhuzao Ji Youse Hejin/Special Cast. Nonferrous Alloy. 37 pp 518-21

[95] Froes, F. 2007. Advances in titanium metal injection molding Powder Metall. Met. Ceram. 46 pp 303-10

[96] Prananingrum, W., Tomotake, Y., Naito, Y., Bae, J., Sekine, K., Hamada, K. and Ichikawa, T. 2016. Application of porous titanium in prosthesis production using a moldless process: Evaluation of physical and mechanical properties with various particle sizes, shapes, and mixing ratios J. Mech. Behav. Biomed. Mater. 61 pp 581-9

[97] Schwanke, C. M., Menegotto, J. C., Gomes, R. M. and Schaeffer, L. 2001. Commercial pure titanium powders obtained by hydrogen embrittlement Key Eng. Mater. 189-191 pp 264-70

[98] Fan, S. G., Dou, Z. H., Zhang, T. A., Liu, Y. and Niu, L. P. 2019. Deoxidation Mechanism in Reduced Titanium Powder Prepared by Multistage Deep Reduction of TiO2 Metall. Mater. Trans. B Process Metall. Mater. Process. Sci. 50 pp 282-90

[99] Choi, W. J., Joo, W., Lim, J. H., Park, K. T., Choi, S. H., J. S. J., Ali, B., Kim, T. S., Hyun, S. K. and Lee, Y. J. 2017. Fabrication Of A Spherical Titanium Powder By Combined Combustion Synthesis And Dc Plasma Treatment. Arch. Metall. Mater. 62 pp 1057-62

[100] Cantin, G. M. D., Kean, P. L., Stone, N. A., Wilson, R., Gibson, M. A., Yousuff, M., Ritchie, D. and Rajakumar, R. 2011. Innovative consolidation of titanium and titanium alloy powders by direct rolling Powder Metall. 54 pp 188-92

[101] Gogaev, K. A., Nazarenko, V. A., Voropaev, V. A., Podrezov, Y. N., Verbilo, D. G., Koryak, O. S. and Okun, I. Y. 2009. Mechanical properties of powder titanium at different production stages. V. Properties of a titanium strip produced by powder rolling. Powder Metall. Met. Ceram. 48 pp 652-8

[102] Dabhade, V. V., Rama-Mohan, T. R. and Ramakrishnan, P. 2007 Nanocrystalline titanium powders by high energy attrition milling Powder Technol. $171 \mathrm{pp}$ 177-83

[103] Yuzhakova, E. A., Kotlyarov, V. I., Beshkarev, V. T, and Ivanov, V. V. 2016 Obtaining of polygonal powder of titanium and its alloys with given granulometric composition for additive technologies Tsvetnye Met. Pp 63-8

[104] Whittaker, D. 2012. Powder processing, consolidation and metallurgy of titanium Powder Metall. 55 pp 6 10 
[105] Sheng, Y., Guo, Z,, Haom J, , Shao, H. and Wang, S. 2013 Preparation of micro-spherical titanium powder by RF plasma Xiyou Jinshu Cailiao Yu Gongcheng/Rare Met. Mater. Eng. 42 pp 1291-4

[106] Friedman, G. 2017 Production Of Titanium Powder By The Rotating Electrode Process. Agard Conf Proc. Available from: https: / / www.scopus.com/inward/record.uri?eid=2-s2.085041988821\&partnerID $=40 \& \mathrm{md} 5=6 \mathrm{f} 8 \mathrm{c} 813 \mathrm{e} 67 \mathrm{e} 46 \mathrm{cd7d} 16275 \mathrm{f} 967 \mathrm{ccd} 6 \mathrm{ea}$

[107] Kanou, O., Fukada, N. and Hayakawa, M. 2015 Production of high-strength titanium alloy using prealloyed powder as a starting material Funtai Oyobi Fummatsu Yakin/Journal Japan Soc. Powder Powder Metall. 62 pp 365-70

[108] Du, C., Wang, Z., Hou, J., Jiao, S. and Zhu, H. 2014. Production of Titanium Powder by Sodiothermic Reduction in $\mathrm{CaCl} 2$ Molten Salts Metall. Mater. Trans. B Process Metall. Mater. Process. Sci. 45 1750-6

[109] Bayat, O., Khavandi, A. R. and Ghasemzadeh, R. 2012. Effect of blend granulometry on calciothermic reduction of TiO2 Int. J. Self-Propagating High-Temperature Synth. 21 151-5

[110] Gogaev, K., Voropaev, V., Kalutskii, G., Podrezov, Y., Verbilo, D. and Koryak, 0. 2013. Production of Titanium Powder Sheets by Asymmetric Rolling. Powder Metall. Met. Ceram. 51 pp 509-17

[111] Jones, M., Horlock, A. J., Shipway, P. H., McCartney, D. G. and Wood, J. V. 2001. A comparison of the abrasive wear behaviour of HVOF sprayed titanium carbide- and titanium boride-based cermet coatings Wear 250 pp 1009-16

[112] Ashraf-Imam, M., Froes, F. H. and Reddy, R. G. 2013. Cost effective developments for fabrication of titanium components. Key Engineering Materials Volume 551

[113] Hurless, B. E. and Froes, F. H. 2002. Cutting the cost of titanium Adv. Mater. Process. 160 37-40

[114] Behrens B-A and Gastan E 2005 Die pressing of complex components from titanium powder Wire 55 pp 16 8

[115] Shui, X., Yamanaka, K., Mori, M., Nagata, Y., Kurita, K. and Chiba, A. 2017. Effects of post-processing on cyclic fatigue response of a titanium alloy additively manufactured by electron beam melting Mater. Sci. Eng. A 680 pp 239-48

[116] Laptev, A., Vyal, O., Bram, M., Buchkremer, H. P. and Stöver, D. 2005 Green strength of powder compacts provided production of highly porous titanium parts Powder Metall. 48 pp 358-64

[117] German, R. M. 2012. Infrastructure Emergence For Metal Injection Molded Titanium Medical devise. Int. J. Powder Metall. 48 pp 33-8

[118] Tuncer, N., Arslan, G., Maire, E. and Salvo, L. 2011. Investigation of spacer size effect on architecture and mechanical properties of porous titanium Mater. Sci. Eng. A 530 pp 633-42

[119] Hu, D., Xiao, W. and Chen, G. Z. 2013 Near-Net-Shape production of hollow titanium alloy components via electrochemical reduction of metal oxide precursors in molten salts Metall. Mater. Trans. B Process Metall. Mater. Process. Sci. 44 pp 272-82

[120] Popescu, S., Jerby, E., Meir, Y., Barkay, Z., Ashkenazi, D., Mitchell, J. B. A., Le Garrec, J. L. and Narayanan, T. 2015. Plasma column and nano-powder generation from solid titanium by localized microwaves in air J. Appl. Phys. Volume 118, Issue 2

[121] Fang, Z. Z. 2010. Powder metallurgy titanium-challenges and opportunities Int. J. Powder Metall. (Princeton, New Jersey) 46 pp 9-10

[122] Wei, M., Chen, S., Guo, K., Liang, J. and Liu, C. 2017. Preparation of TA15 Titanium Alloy Powder by EIGA for Laser 3D Printing Cailiao Daobao/Materials Rev. 31 pp 67 and 78

[123] Lin, D., Chung, S. T., Kwon, Y. S. and Park, S. J. 2016. Preparation of Ti-6Al-4V feedstock for titanium powder injection molding J. Mech. Sci. Technol. 30 pp 1859-64

[124] Cai, Y., Chen, Q. and Ding, Y. 2005. Research of injection molding titanium parts Fenmo Yejin Jishu/Powder Metall. Technol. 23 pp 449-55

[125] Lu, L., Zhang, S., Xu, J., Zhao. X., Sheng, Y. and Zhang, J. 2017. Review on advanced preparation technology of spherical titanium powders Xiyou Jinshu/Chinese J. Rare Met. 41 pp 94-101

[126] Whittaker, D. 2006. SWOT testing for PM titanium at Prague gathering Met. Powder Rep. 61 pp 8-12

[127] Schwanke, C. M. and Schaeffer, L. 1999. Technologies and principles for titanium powder production by $\mathrm{P} / \mathrm{M}$-a review Mater. Sci. Forum 299-300. Available from : https://www.scopus.com/inward/record.uri?eid=2-s2.04244192890\&partnerID=40\&md5=c1ebe4d7e20036bb3054eb11bc88eea7

[128] Froes, F. H., Gungor, M. N. and Imam, M. A. 2006. Technology Developments: Cost affordable titanium An update Mater. Technol. $21 \mathrm{pp}$ 206-9

[129] Klug, K. L., Ucok, I., Gungor, M. N., Guclu, M., Kramer, L. S., Tack, W. T., Nastac, L., Martin, N. R. and Dong, H. 2004. The near-net-shape manufacturing of affordable titanium components for the M777 lightweight howitzer JOM 56 pp 35-41

[130] Barreiro, M. M., Grana, D. R., Kokubu, G. A., Luppo, M. I., Mintzer, S. and Vigna, G. 2010. Titanium compacts produced by the pulvimetallurgical hydride-dehydride method for biomedical applications Biomed. Mater. Volume 5, Issue 2

[131] Sutcliffe, P. W. and Morton, P. H. 2017. Titanium Powder Production By The Harwell Centrifugal Shot Casting Process. AGARD Conf Proc. Available from: https://www.scopus.com/inward/record.uri?eid=2s2.0-85041991530\&partnerID=40\&md5=45677e6541a57841631a4d8d3782a279

[132] Liu, H. W. and Plucknett, K. P. 2017. Titanium aluminide (Ti-48Al) powder synthesis, size refinement and sintering Adv. Powder Technol. 28 pp 314-23

[133] Ward-Close, C. M., Godfrey, A. B. and Thompson, S. R. 2005. Titanium made the EDO way should see prices drop Met. Powder Rep. 60 pp 20-5 
[134] Okabe, T. H., Oda, T. and Mitsuda, Y. 2004. Titanium powder production by preform reduction process (PRP) J. Alloys Compd. 364 pp 156-63

[135] Henriques, V. A. R., Sandim, H. R. Z. and Da Silva, C. R. M. 2003. Use of Titanium Powders Obtained by Sponge Screening and for the HDH Process in Titanium Alloy Production for Powder Metallurgy (P/M) Mater. Sci. Forum 1 pp 23-8

[136] Yu, C., Cao, P. and Jones, M. I. 2017. Titanium powder sintering in a graphite furnace and mechanical properties of sintered parts Metals (Basel). 7. Available from: https: / / www.scopus.com/inward/record.uri?eid=2-s2.085013924476\&doi=10.3390\%2Fmet7020067\&partnerID=40\&md5=abec15fe33ac1b7f73ee8f6518bf1722

[137] Zhu, Z. S., Wang, Q. R. and Sha, A. X. 2003. Thermal stability and high temperature properties of TC6 titanium alloy at conventionally annealed state Hangkong Cailiao Xuebao/Journal Aeronaut. Mater. 23 pp 5-9

[138] Amarchand, S., Ramamohan, T. R. and Ramakrishnan, P. 2001. Synthesis of fine titanium powders via solution route Miner. Process. Extr. Metall. Rev. 22 pp 279-85

[139] Zheng, H., Ito, H. and Okabe, T. H. 2007. Production of titanium powder by the calciothermic reduction of titanium concentrates or ore using the preform reduction process Mater. Trans. 48 pp 2244-51

[140] German, R. M. 2010. Materials for microminiature powder injection molded medical and dental devices Int. J. Powder Metall. (Princeton, New Jersey) 46 pp 15-8 